\title{
Analisis Kadar IFN- $\gamma$ dan IL-10 pada PBMC Penderita Tuberkulosis Aktif, Laten dan Orang Sehat, Setelah di Stimulasi dengan Antigen ESAT-6
}

\author{
Heru Setiawan, Jusak Nugraha \\ Program Studi S2 Imunologi, Sekolah Pascasarjana Universitas Airlangga \\ J1. Airlangga No. 4-6 Surabaya, Jawa Timur, Telp. (031)5914042 \\ hr_setya@yahoo.co.id, jusak.nugraha@yahoo.com
}

\begin{abstract}
Abstrak
Latar Belakang : Tuberkulosis paru disebabkan oleh bakteri Mycobacterium tuberculosis, yakni baksil tahan asam yang hidup secara intraseluler dan merupakan penyebab utama kematian penyakit menular. Oleh karenanya, perlu diagnosis dini untuk pencegahan. Sel Th1 sangat berperan pada sistem pertahanan tubuh dalam menghadapi infeksi bakteri intraseluler. Pada tuberkulosis paru, terjadi ketidakseimbangan sistem imun host. Tujuan penelitian ini adalah menganalisis kadar IFN- $\gamma$ dan IL-10 pada PBMC (peripheral blood mononuclear cell) penderita tuberkulosis aktif, laten dan orang sehat, setelah stimulasi dengan antigen ESAT-6. Metode Penelitian : Subjek penelitian adalah 10 TB aktif, 10 LTBI dan 10 orang sehat, yang diambil dari RS Paru Karang Tembok Surabaya. Dilakukan pengambilan darah vena kemudian diisolasi PBMCnya dan dikultur dengan ESAT-6. Kemudian supernatan diambil untuk dilakukan pemeriksaan kadar IFN- $\gamma$ dan IL-10 dengan metode pemeriksaan Enzyme Linked Immunosorbent Assay (ELISA).Hasil : Kadar IFN- $\gamma$ setelah di stimulasi antigen ESAT-6, pada orang sehat berkisar antara 95,84-135,47 pg/mL, pada TB laten 74,6-142,2 pg/mL dan TB aktif 72,67$154,21 \mathrm{pg} / \mathrm{mL}$. Kadar IL-10 setelah di stimulasi antigen ESAT-6, pada orang sehat berkisar antara 161,89 - 282,57 pg/mL, pada TB laten 145,28 - 218,64 pg/mL dan TB akti 232,05 - 294,07 pg/mL. Hasil analisis menunjukkan terdapat perbedaan bermakna $(\mathrm{p}=0,000)$ kadar $\mathrm{IL}-10$ pada ketiga kelompok.Simpulan : Terdapat perbedaan pola sekresi/ kadar IFN- $\gamma$ dan IL-10 pada PBMC penderita TB aktif, TB laten dan orang sehat.
\end{abstract}

Kata kunci : IFN- $\gamma$, IL-10, TB aktif.

\begin{abstract}
Background : Pulmonary tuberculosis is caused by Mycobacterium tuberculosis which are acid fast bacilli intracellularly and is a major cause of death from infectious disease in the world. Therefore, early diagnosis is needed in order to prevention. Th1 cells play an important role in the body's defense system against intracellular bacterial infections. Patients with TB have immune system disorders. The purpose of this study was to analyze the levels of IFN- $\gamma$ and $I L-10$ patients with active TB, latent TB and healthy persons.Methods : The subjects were 10 active TB, 10 LTBI and 10 healthy persons from the Pulmonary Hospital Surabaya. Venous blood was taken, then PBMC was isolated and cultured with ESAT-6. The supernatant was taken for examination of IFN- $\gamma$ and IL-10 levels by Enzyme Linked Immunosorbent Assay (ELISA). Result : Levels of IFN- $\gamma$ after stimulation with ESAT-6 antigen, in healthy individuals ranged from 95,84 to $135,47 \mathrm{pg} / \mathrm{mL}$, Latent TB 74,6 to $142,2 \mathrm{pg} / \mathrm{mL}$ and active TB from 72,67 to 154,21 $\mathrm{pg} / \mathrm{mL}$. While, levels of IL-10 in healthy individuals ranged from 161,89 to 282,57 pg/mL, Latent TB 145,28 to $218,64 \mathrm{pg} / \mathrm{mL}$ and active TB 232,05 to294,07 pg/mL. The analysis showed a significant
\end{abstract}

JBP Vol. 18, No. 1, April 2016-Heru Setiawan 
differences $(p=0,000)$ in levels of IL-10 in alla three groups.Conclusions : Differences in the levels of $I F N-\gamma$ and IL-10 in PBMC of patients with active TB, latent TB and healthy persons were shown.

Keywords : IFN- $\gamma, I L-10$, active TB.

\section{PENDAHULUAN}

Tuberkulosis (TB) merupakan penyakit infeksi bakteri menahun yang disebabkan oleh Mycobakterium tuberculosis, suatu basil tahan asam yang ditularkan melalui udara. Tuberkulosis paru bila tidak ditangani dengan benar akan menimbulkan komplikasi seperti: pleuritis, efusi pleura, laringitis dan TB usus. Tuberkulosis merupakan penyebab kematian utama di dunia (Day, 2011). Kematian karena tuberkulosis sekitar 1,5 juta hingga 2 juta orang setiap tahun di negara berkembang termasuk Indonesia.

Infeksi TB masih menjadi masalah kesehatan di Indonesia. Berdasarkan laporan WHO 2013 Indonesia berada di rangking kelima insiden TB, setelah India ( $2-2,3$ juta), Cina $(0,9$ - 1,1 juta), Nigeria ( $340-880$ ribu), Pakistan $(370-650$ ribu ). Insiden TB di Indonesia (410 - 520 ribu). Menurut hasil Riskesdas 2013 prevalensi TB berdasarkan diagnosis sebesar $0,4 \%$ dari jumlah penduduk. Setiap 100 ribu penduduk Indonesia terdapat 400 orang yang didiagnosis kasus TB oleh tenaga kesehatan. Hasil Riskesdas 2013 tersebut tidak berbeda dengan Riskesdas 2007, mendapatkan angka prevalensi TB paru 0,4\% (Kemenkes Republik Indonesia, 2014).

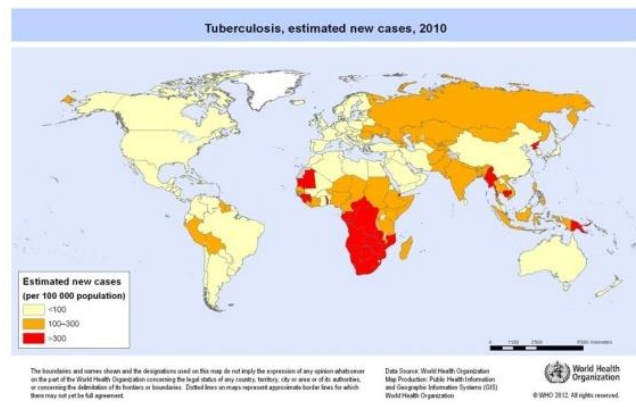

Gambar 1.1 Peta distribusi tuberkulosis.
Tuberkulosis sebagai global emergency, telah menginfeksi sepertiga penduduk dunia. Penderita tuberkulosis di kawasan Asia terus bertambah. Sejauh ini, Asia termasuk kawasan dengan penyebaran tuberkulosis tertinggi di dunia. Setiap 30 detik, ada satu pasien di Asia meninggal dunia akibat penyakit ini (Kaihena, 2013). Setiap tahun, terdapat lebih dari 500.000 kasus baru tuberkulosis, dan 75 persen penderita termasuk kelompok usia produktif. Sekitar $75 \%$ penderita tuberkulosis adalah kelompok usia produktif secara ekonomis (15-50 tahun). Diperkirakan seorang pasien tuberkulosis dewasa, akan kehilangan rata-rata waktu kerjanya 3 sampai 4 bulan (Harari, 2011).

Seseorang yang terinfeksi Mycobactrium tuberculosis akan timbul respons imun, ditandai dengan pembentukan granuloma (Sutherland, 2011). Individu yang terinfeksi kuman TB, sekitar 10\% berkembang menjadi TB aktif dan sisanya 90\% infeksi TB laten, ditandai dengan respons imun melawan bakteri (tes tuberkulin positif), tanpa disertai infeksi klinis aktif baik secara mikrobiologis maupun radiologis. Tuberkulosis laten mempunyai potensi teraktifasi kembali menjadi tuberculosis aktif eksaserbasi akut dan menjadi sumber infeksi baru. Orang dengan TB laten dapat sehat selama bertahun-tahun karena sembuh spontan tetapi mempunyai resiko yang tinggi untuk menjadi TB aktif selama hidupnya (Gyoung, 2013).

Diagnosis TB laten selama ini dengan uji kulit tuberkulin (tuberculin skin test/ TST) yang menggunakan purified protein derivative (PPD). Uji ini kurang spesifik karena terdapat reaksi silang dengan antigen mycobacterium lain dan vaksinasi Bacillus Calmette-Guerin (BCG) sehingga memberikan hasil positif palsu (Pratomo, 2013).

Para ahli saat ini menduga adanya gangguan sistim imun pada penderita TB. Sel T helper-1 (Th1) sangat berperan dalam sistim 
pertahanan tubuh terutama dalam menghadapi infeksi bakteri intraseluler (Teguh, 2010). Pergeseran keseimbangan antara produksi sitokin dari sel Th1 dan Th2 dapat menentukan perkembangan penyakit. Respon imun terhadap Mycobacterium tuberculosis selain respon imun sel Th1 yang protektif juga dapat merangsang respon imun sel Th2 yang diduga tidak protektif (Handojo, 2004).

Produksi sitokin anti inflamasi seperti IL-10 (diproduksi oleh sel Th2) dalam menanggapi kuman tuberculosis dapat menurunkan respon imun dan membatasi kerusakan jaringan dengan menghambat respon inflamasi yang berlebihan. Sitokin ini jika diproduksi berlebihan dapat menyebabkan kegagalan untuk mengendalikan infeksi yang menyebabkan perluasan penyakit tuberculosis. (Sharma, 2001)

Interleukin-10 (IL-10) merupakan sitokin yang telah diidentifikasikan sebagai faktor penghambat sitokin-sitokin. IL-10 diproduksi oleh sel-sel Th2, subset sel T CD4+ termasuk Th1 dan Th17, sel B, neutrofil, makrofag dan beberapa subset sel dendritik. IL10 dapat menghambat kemampuan sel myeloid seperti makrofag dan sel dendritik untuk mengaktifkan sel-sel Th1, sehingga produksi sitokin dari Th1 dapat terhalang. IL-10 juga dapat menghambat proses fagositosis dan eliminasi mikroba seperti $M$. tuberkulosis dengan cara membatasi produksi intermediate oksigen dan nitrogen reaktif yang dimediasi oleh aktifasi INF- $\gamma$. IL-10 juga dapat menghambat pematangan fagosom sehingga memfasilitasi kelangsungan hidup dan perkembangan basil $M$. tuberculosis (Redford,2011). Kenaikan kadar IL-10 pada serum penderita tuberculosis menghambat produksi IFN- $\gamma$ dan sitokin-sitokin tipe 1 dalam merespon antigen Mycobacterium tuberculosis (Vankayalapati, 2002). Berdasarkan penjelasan dari berbagai literatur, produksi IL10 di dalam tubuh, khususnya pada penderita TB menunjukkan peranan yang sangat penting dalam progresivitas penyakit TB.

Mycobacterium tuberculosis yang aktif secara metabolik, memproduksi protein sekresi berupa Early secreted antigenic target $\mathrm{kDa} 6$ (ESAT-6) dan Culture Filtrate Protein 10 (CFP-
10). ESAT-6 dan CFP-10 berpotensi untuk digunakan sebagai antigen dalam diagnosis tuberkulosis. Kedua antigen sekresi faktor virulensi tersebut menstimulus aktivasi limfosit $\mathrm{T}$ sehingga memproduksi interferon gamma (IFN- $\gamma$ ), TNF- $\alpha$ dan menginduksi makrofag untuk memproduksi interleukin 10 (IL-10) (Masniari, 2013).

Adanya kuman TB pada makrofag akan memberi sinyal, sehingga retikulum endoplasmik memproduksi molekul MHC kelas II. Molekul ini akan membawa fragmen kuman TB yang diproses oleh makrofag ke permukaan makrofag dan dipaparkan, sehingga dikenali dan diikat oleh reseptor limfosit $\mathrm{T}-\mathrm{CD}^{+}$. Sel

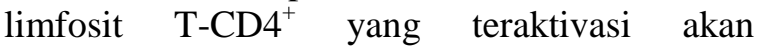
memproduksi sitokin yang penting dalam menghancurkan atau mengontrol pertumbuhan kuman TB. Sitokin utama adalah Interferon Gamma, TNF alfa dan interleukin 2. Salah satu sitokin yang diproduksi oleh sel $\mathrm{T}-\mathrm{CD} 4^{+}$adalah IFN- $\gamma$ yang berperan penting dalam mengeliminasi Mycobacterium tuberculosis. Interferon Gamma memperkuat potensi fagosit makrofag yang terinfeksi M.Tb, yaitu dengan cara menstimulasi pembentukan fagolisosom. Interferon Gamma juga menstimulasi pembentukan radikal bebas yang dapat menghancurkan komponen M.Tb. Interferon Gamma akan merangsang makrofag yang mengandung kuman TB untuk meningkatkan reactive nitrogen intermediate (RNI) yang diperlukan untuk menghancurkan kuman TB (Abbas et al., 2014).

Penelitian tuberkulosis terus dilakukan berkelanjutan dalam mencari solusi yang tepat mematahkan rantai patofisiologi biomolekuler tuberkulosis (Corbiere, 2012). Penelitian penemuan vaksin untuk tuberkulosis, parameter antigenik baik secara protein, gen, sitokin dan teori imunologi lainnya dalam rangka mendeteksi mekanisme imun untuk mengeliminasi patogenitas. Kemampuan kuman untuk tetap hidup dalam suasana respons imun yang kuat, menunjukkan adanya mekanisme penghindaran dari kuman tuberculosis (Pollock, 2013).

Mengetahui kadar IFN- $\gamma$ dan IL-10 terhadap stimulus antigen ESAT-6, dapat 
diketahui spesifisitas potensial antibodi pada imunodiagnostik tuberkulosis, memprediksi aktivitas virulensi antigen dalam inang (Kenyorini, 2012). Pemeriksaan serologi untuk mendiagnosis tuberkulosis aktif dan laten diperlukan pada kasus saat pemeriksaan rutin sederhana dan radiologi tidak membantu (Corbiere, 2012). Penelitian pemeriksaan imunologi terus berkembang untuk mendeteksi antibodi/ respons imun terhadap antigen tuberkulosis. Diperlukan kombinasi beberapa pemeriksaan untuk meningkatkan sensitivitas dan spesifisitasnya (Hermayanti, 2014).

Insiden TB yang tinggi dan adanya keterbatasan klinik, bakteriologi dan radiologi dalam menilai keberhasilan pengobatan TB, penelitian ini membandingkan respons imun seluler inang terhadap penderita TB laten, TB aktif dan orang sehat, terutama ekspresi Interferon Gamma dan Interleukin 10 setelah stimulasi dengan antigen ESAT-6.

\section{TINJAUAN PUSTAKA}

\subsection{Batasan Tuberkulosis (TB).}

Tuberkulosis yaitu penyakit infeksi yang disebabkan oleh bakteri Mycobacterium tuberculosis, terutama pada paru paru. Penyebaran TB dari orang ke orang lewat droplet di udara. Penderita TB paru batuk, bersin atau meludah, mereka menularkan bakteri TB di udara (WHO, 2014b). Orang yang terinfeksi bakteri TB mempunyai resiko menderita sakit TB sebesar $10 \%$ dan pada pasien immunocompromised seperti pada penderita HIV, malnutrisi, diabetes dan pengobatan immunosupresan mempunyai resiko lebih besar untuk menderita penyakit TB. Tanpa pengobatan yang adekuat, $2 / 3$ pasien TB akan meninggal. Tahun 2000 lebih dari 37 juta nyawa dapat diselamatkan dengan diagnosis dan terapi yang efektif (WHO, 2014d).

\subsection{Patogenesis}

Kuman tuberkulosis ditularkan dari orang ke orang melalui inhalasi dari tetesan kecil (droplet infection) yang berisi Mycobacterium tuberculosis. Kemudian kuman tuberkulosis masuk ke bronkus dan alveoli paru, terjadilah infeksi primer. Selanjutnya menyebar ke kelenjar getah bening setempat (limfangitis lokal). Peradangan tersebut diikuti oleh pembesaran kelenjar getah bening di hilus (limfangitis regional). Infeksi primer dan limfangitis regional dinamakan TB primer, yang dalam perjalanan lebih lanjut akan mengalami salah satu sebagai berikut :

1. Sembuh dengan tidak meninggalkan cacat sama sekali (lebih dari 90\%).

2. Sembuh dengan meninggalkan sedikit bekas (garis fibrotik atau perkapuran

di hilus).

3. Menyebar dengan cara per continuitatem (melalui jaringan sekitarnya),

bronkogen,

hematogen dan limfogen. Penyebaran ini berkaitan dengan daya tahan tubuh, jumlah dan virulensi kuman (PDPI, 2002).

Tuberkulosis postprimer dimulai dengan sarang dini, yang umumnya terletak di segmen apikal lobus superior maupun lobus inferior. Sarang dini ini awalnya berbentuk suatu sarang pneumonik kecil yang dapat sembuh dengan jalan resorbsi fibrosis atau perkapuran, dan dapat menjadi progresif yaitu proses bertambah luas dengan pengejuan dan timbul kavitas. Bila ada kavitas dapat sembuh di satu bagian namun menimbulkan sarang pneumonik baru yang tetap aktif dan meluas. (PDPI, 2002).

\subsection{Gejala klinis}

Gejala utama pasien TB paru adalah batuk berdahak selama 2-3 minggu atau lebih. Batuk dapat diikuti gejala respiratorik lain, yaitu batuk berdahak bercampur darah atau batuk darah, sesak napas, nyeri dada. Gejala respiratorik ini sangat bervariasi, dari mulai tidak ada gejala sampai gejala yang cukup berat tergantung dari luas lesi (Depker RI, 2011).

Gejala sistemik juga dapat terjadi pada penderita TB yaitu demam lebih dari satu bulan, malaise, berkeringat malam hari tanpa kegiatan fisik, nafsu makan menurun, berat badan menurun (PDPI, 2002).

Gejala tersebut diatas dapat dijumpai pula pada penyakit paru selain TB, seperti bronkiektasis, bronchitis kronis, asma, kanker paru dll. Namun karena prevalensi TB di 
Indonesia masih tinggi, maka setiap orang yang dating ke sarana pelayanan kesehatan dengan gejala tersebut diatas, dianggap sebagai tersangka pasien TB (Depkes RI, 2011).

Gejala TB ekstra paru, tergantung dari organ yang terinfeksi, misalnya limfadenitis TB yaitu terjadi pembesaran yang lambat dan tidak nyeri dari kelenjar getah bening, pada meningitis TB akan terlihat gejala meningitis, pada pleuritis TB akan terdapat gejala sesak napas, nyeri dada pada sisi rongga pleura yang terkena infeksi (PDPI, 2002).

\subsection{Diagnosis}

Diagnosis TB paru pada orang dewasa ditegakkan dengan ditemukannya kuman TB (baksil tahan asam) pada sediaan hapusan dahak pasien dengan suspek TB, yang diambil dalam waktu dua hari, yaitu sewaktu-pagi-sewaktu (SPS) (Depkes RI, 2011).

Foto thoraks tidak selalu memberikan gambaran yang khas pada TB paru, sehingga tidak dibenarkan mendiagnosis TB hanya berdasarkan foto thoraks saja. Gambaran radiologis yang dicurigai sebagai lesi TB aktif antara lain (PDPI, 2002):

a. Bayangan berawan/ nodular di segmen apikal dan posterior lobus atas paru dan segmen posterior lobus bawah.

b. Kavitas yang dikelilingi oleh bayangan buram berawan atau nodular.

c. Bercak milier.

d. Efusi pleura unilateral (pada umumnya).

Pemeriksaan foto toraks, biakan dan uji kepekaan dapat digunakan sebagai penunjang diagnosis dan jika sesuai dengan indikasinya.

Diagnosis TB laten berdasarkan riwayat penyakit, hasil TST atau IGRA (Interferon Gamma Release Assay), foto toraks, pemeriksaan fisik dan pemeriksaan sputum. Perbedaan antara TB laten dan TB aktif ditunjukkan pada tabel dibawah ini:

Tabel 1. Perbedaan TB laten dengan TB aktif (CDC, 2010)

\begin{tabular}{|ll|cl|}
\hline \multicolumn{2}{|c|}{ TB Laten } & \multicolumn{3}{|c|}{ TB Aktif } \\
\hline$\bullet$ & $\begin{array}{l}\text { Tidak ada gejala } \\
\text { dan TB aktif }\end{array}$ & $\bullet$ & $\begin{array}{l}\text { Terdapat gejala } \\
\text { TB aktif }\end{array}$ \\
\hline$\bullet$ & Hasil TST dan & $\bullet$ & Hasil TST atau \\
\hline
\end{tabular}

\begin{tabular}{|ll|ll|}
\hline \multicolumn{2}{|l|}{ IGRA positif } & \multicolumn{2}{|l|}{$\begin{array}{l}\text { IGRA biasanya } \\
\text { positif }\end{array}$} \\
\hline$\bullet$ & $\begin{array}{l}\text { Foto toraks } \\
\text { normal }\end{array}$ & $\bullet$ & $\begin{array}{l}\text { Foto toraks tidak } \\
\text { normal }\end{array}$ \\
\hline$\bullet$ & $\begin{array}{l}\text { Hapusan atau } \\
\text { kultur dahak } \\
\text { paru negative }\end{array}$ & $\bullet \begin{array}{l}\text { Hapusan atau } \\
\text { kultur dahak } \\
\text { paru positif }\end{array}$ \\
\hline$\bullet$ & Tidak menular & $\bullet$ & $\begin{array}{l}\text { Sering menular } \\
\text { sebelum diobati }\end{array}$ \\
\hline
\end{tabular}

\subsection{Tuberkulosis Aktif}

Infeksi tuberkulosis aktif adalah tuberkulosis yang dapat menularkan, penyakit tuberkulosis pada umumnya mengenai paru paru, yang menyebar melalui udara ketika penderita tubekculosis tersebut bersin, batuk yang tidak ditutup dan berbicara (Jordao, 2011). Basil tuberkulosis dapat tetap diudara selama beberapa jam, terutama di daerah padat, kurang ventilasi udara, kurang cahaya dan lembab. Tuberkulosis aktif semakin berkembang pada penderita dengan stress fisik, malnutrisi, kurang higienis, manula, HIV/AIDS serta penyakit dengan defisiensi imun lainnya (Devi, 2012). Kuman tuberkulosis dapat menyebar melalui pembuluh darah, kelenjar getah bening, sehingga dapat menginfeksi hampir seluruh organ tubuh seperti paru-paru, otak, ginjal, saluran pencernaan, tulang, kelenjar getah bening (Zhang, 2011).

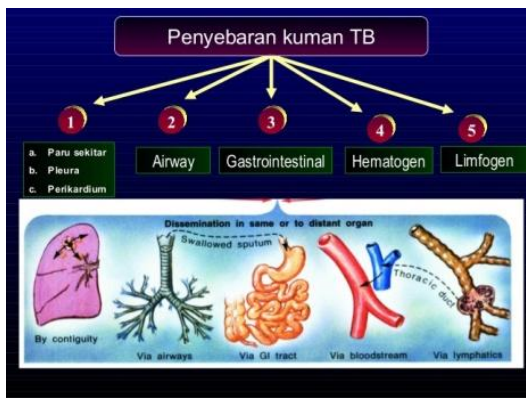

Gambar 2.1 Invasi dan migrasi tuberkulosis (Afif , 2013).

Morfologi bakteri Mycobacterium tuberculosis berbentuk batang lurus atau sedikit melengkung, tidak berspora dan tidak berkapsul. Bakteri berukuran lebar 0,3 - 0,6 $\mathrm{mm}$ dan panjang $1-4 \mathrm{~mm}$. Dinding $M$. tuberculosis 
sangat kompleks, terdiri dari lapisan lemak cukup tinggi (60\%). Penyusun utama dinding sel M. tuberculosis adalah asam mikolat, lilin kompleks, trehalosa dimikolat dan mycobacterial sulfolipids yang berperan dalam virulensi (Fitriani, 2011). Unsur lain di dinding sel bakteri adalah polisakarida. Struktur dinding sel yang kompleks tersebut menyebabkan bakteri Mycobacterium tuberculosis bersifat tahan asam. Komponen antigen di dinding sel dan sitoplasma, yakni komponen lipid, polisakarida dan protein (ESAT-6, CFP-10).

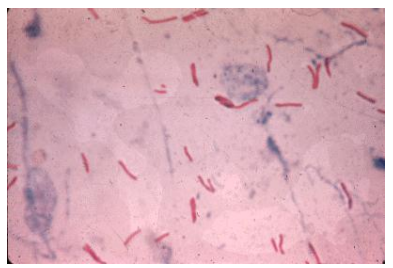

Gambar 2.3 Bakteri Mycobacterum tuberculosis (Gustiani, 2014).

\subsection{Tuberkulosis Laten/ Laten $M$. Tuberculosis Infection.}

Tuberkulosis laten adalah sindroma tuberkulosis klasik yang terjadi setelah seseorang terpapar dengan Mycobacterium tuberculosis, kemudian terjadi keseimbangan antara respons imun host dengan agent Mycobacterium tuberculosis (Widjaja, 2011). Individu tersebut tidak menunjukkan gejala klinis, tidak menular, tidak menunjukkan kuman secara mikroskopik, juga tidak ada tanda tuberkulosis pada radiologis, namun tetap beresiko berkembang menjadi tuberkulosis aktif. Lima hingga sepuluh persen kasus tuberkulosis laten akan berkembang menjadi tuberkulosis aktif dan resiko menjadi tuberkulosis aktif tetap ada seumur hidup (Siswanto, 2009). Diagnosis serta penanganan kasus tuberkulosis laten menjadi sangat penting untuk menekan angka kejadian tuberkulosis aktif.

Tuberkulosis menahun terutama menjadi masalah kesehatan masyarakat. Dimulai dari sarang dini in aktif yang bisa diresorbsi kembali oleh tubuh dan penderita sembuh dengan terbentuk jaringan fibrosis. Sarang tersebut dapat menjadi aktif kembali membentuk jaringan keju dan menimbulkan kavitas. Kavitas awalnya berdinding tipis, kemudian dindingnya menebal/ sklerotik. Kavitas bisa meluas kembali dan menimbulkan sarang pneumonik baru (WHO, 2011). Sarang pneumonik dapat memadat dan membungkus diri (tuberkuloma). Tuberkuloma bisa mengapur dan menyembuh, atau bisa aktif kembali, mencair lagi dan menjadi kavitas lagi. Kavitas dapat menjadi bersih dan menyembuh (open healed cavity). Kavitas dapat menyembuh dengan membungkus diri, akhirnya mengecil seperti bintang (stellate shaped) (Indah, 2013).

\subsection{Respons Imun pada Tuberkulosis Paru.}

Tuberkulosis merupakan penyakit yang pada umumnya menyerang paru paru.. Inhalasi droplet di fagosit oleh makrofag alveolar. Makrofag berusaha menghancurkan patogen dan mengangkutnya ke saluran kelenjar limfe. Lesi granulomatous yang berisi bakteri terbentuk kemudian. Granula tidak secara langsung menyebabkan penyakit. Resiko berkembangnya penyakit tetap ada, karena bakteri tidak di eradikasi. Pada individu dengan sistem imun kompromis, penyakit akan berkembang setelah infeksi primer. Pada individu dengan imunodefisiensi, berkembangan tuberkulosis akan lebih cepat. (Kaufmann, 2002)

Saat awal infeksi, makrofag merupakan sel target utama, setelah teraktifasi akan membunuh bakteri dan berpartisipasi dalam respons protektif sel tipe-1 $\mathrm{T}$ helper (imunitas seluler) dan respons Th2 untuk target ekstraseluler (imunitas humoral) (Marino, 2004). Tipe sitokin Th-1 paling utama dalam imunitas protektif. Sel dendritik melepas sitokin yang diinduksi oleh Th-1 yaitu IL-12 dan IFN-a. Makrofag yang terinfeksi memproduksi sitokin proinflamasi IL-10, IL-4 (Indah, 2013).

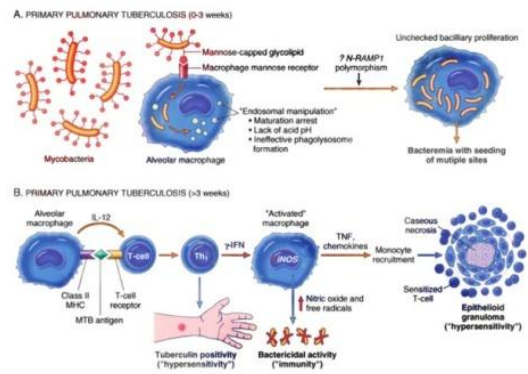


Gambar 2.4 Respons imun pada tuberkulosis aktif

Sumber : Kumar V, Abbas AK, Fausto N, Aster JC. Robbins and Cotran Pathologic Basis of Disease. Ed 8. Philadelphia : Saunders Elseviers; 2010.

Tahun 2001, tes tuberkulin sebagai pemeriksaan imunologi untuk mendiagnosis infeksi Mycobacterium tuberculosis di Amerika Serikat, baik tuberkulosis aktif maupun tuberkulosis laten (Laurens, 2000). Seiring perkembangan penelitian penyakit tuberkulosis di tingkat genom, biomarker interferon gamma (IFN- $\gamma$ ), TNF- $\alpha$ dan IL-10 dihasilkan tubuh sebagai reaksi imun terhadap bakteri Micobacterium tuberculosis (Palomino, 2007).

\subsection{Early Secreted Antigen Target (ESAT-6)}

Early secreted antigen target (ESAT-6) adalah antigen yang disekresi oleh Mycobacterium tuberculosis dan wild type Mycobacterium bovis, namun tidak dijumpai pada vaksin Bacille Calmette Guerin (BCG) (Ganguly, 2008). Pengukuran terhadap respons antigen ini melalui deteksi produksi interferon gamma. Pengeluaran IFN- $\gamma$ dapat diukur dengan penilaian supernatan dari sel yang distimulasi ESAT-6 spesifik sel CD-4 (Lume, 2010).

\section{5}

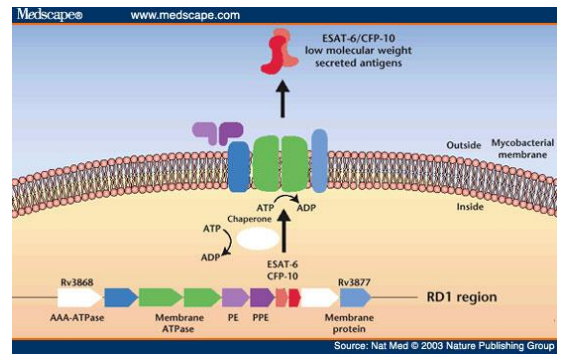

Sintesis ESAT-6 \& CFP-10 oleh Mycobacterium tuberculosis

\subsection{Sitokin}

Sitokin adalah protein yang di sintesis oleh sel yang dapat mempengaruhi sel lainnya. Sitokin dapat sebagai mediator, pengatur imunitas, inflamasi, hematopoesis. Sitokin bisa bereaksi secara sinergis dengan dua atau lebih sitokin lain, bersama sama atau secara antagonis (Gustiani, 2014). Sitokin memicu pelepasan sitokin lainnya, dan sitokin juga dapat berperan mencegah reaksi berlebihan inflamasi. Sitokin merupakan sinyal penting untuk mengaktifkan kerja sel yang lain, sehingga jenis sitokin yang dihasilkan tersebut memberikan efek pada sel targetnya (Afif, 2013). Sitokin imunologi tipe 1 atau sel tipe Th1 yang meningkatkan respons imun seluler (IFN- $\gamma$, TNF- $\alpha$, TGF- $\beta$, IL- 1, IL-2, IL-11, IL-12, IL-18). Sitokin Th-1 mengaktifkan makrofag, membentuk sitokin pro inflamasi dan menginduksi mekanisme imun efektor sitotoksik dari makrofag. Sel tipe Th2 yang mendukung respons antibodi (IL-4, IL-5, IL-6, IL-10, IL-13). Sitokin Th-2 menginduksi pembentukan antibodi, juga menghambat fungsi makrofag, disebut sebagai sitokin anti inflamasi (Kusuma, 2007).

\subsubsection{Interferon gamma (IFN- $\gamma$ )}

Interferon gamma di produksi oleh limfosit sel $\mathrm{T}$ helper dan bekerja pada sel makrofag, sel endotel, fibroblast, sel T sitotoksik dan limfosit B anti-viral (Jalius, 2012). Interferon gamma di hasilkan selama respons imun berlangsung oleh adanya antigen spesifik sel $\mathrm{T}$ dan natural killer cells (sel NK) yang di stimulasi oleh IL-2.(Roostati, 2008). Pengaruhnya mengaktifkan makrofag untuk meningkatkan fagositosis dan kemampuan membunuh sel tumor, meningkatkan pertumbuhan sel $\mathrm{T}$ sitolitik dan sel NK. Aktivitas IFN- $\gamma$ lainnya yakni meningkatkan presentasi antigen oleh makrofag, mengaktifkan aktivitas lisosom di dalam makrofag, meningkatkan aktivitas Th2, mempengaruhi sel normal untuk meningkatkan ekspresi molekul MHC kelas I, mempromosikan adesi dan mengikat leukosit yang bermigrasi, mempromosikan aktivitas sel NK dan mengaktifkan APCs, merangsang diferensiasi Th1 dengan pengaturan transkripsi faktor $\mathrm{T}$ (Widjaja, 2010).

IFN- $\gamma$ meregulasi ekspresi antigen MHC-1 dan menginduksi MHC kelas II. Dengan diaktifkannya MHC kelas II pada sel endotel, sel tersebut menjadi peka terhadap aksi sel T sitolitik spesifik kelas II (Kusuma, 2007). 


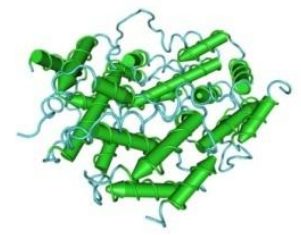

Gambar 2.6 Struktur interferon gamma (Nature reviews Immunology 2011)

\subsubsection{Interleukin- 10 (IL-10).}

Interleukin-10 (IL-10) merupakan sitokin yang telah diidentifikasikan sebagai faktor penghambat sitokin. IL-10 diproduksi oleh sel Th2, subset sel T CD4+ termasuk Th1 dan Th17, sel B, neutrophil, makrofag dan beberapa subset sel dendritik. IL-10 dapat menghambat kemampuan sel mieloid seperti makrofag dan sel dendritik untuk mengaktifkan sel Th1, sehingga produksi sitokin dari Th1 dapat terhalang. Il-10 juga dapat menghambat proses fagositosis dan eliminasi mikroba seperti M. tuberculosis dengan cara membatasi produksi intermediate oksigen dan nitrogen reaktif yang dimediasi oleh aktifasi IFN- $\gamma$. IL-10 dapat menghambat pematangan fagosom sehingga memfasilitasi kelangsungan hidup dan perkembangan baksil Mycobacterium tuberculosis (Redford et al, 2011). IL-10 terbukti menyebabkan penurunan terhadap sekresi dan transkripsi IL-8 yang berfungsi mengerahkan leukosit menuju formasi granuloma pada penyakit tuberculosis (Ameixa and Friedland, 2001).

Berbagai studi telah mengidentifikasi bahwa IL-10 berkorelasi dengan kerentanan terhadap tuberculosis, baik pada manusia maupun hewan percobaan (mencit). Pada penderita tuberkulosis IL-10 dapat ditemukan pada serum dan cairan bronkoalveolar. IL-10 dianggap memungkinkan untuk menjadi biomarker klinis yang penting terhadap progesivitas penyakit (Beamer, 2008).

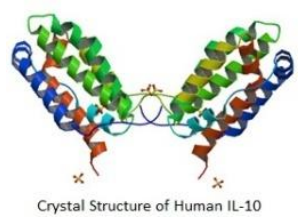

JBP Vol. 18, No. 1, April 2016-Heru Setiawan
Gambar 2.7 Struktur IL-10 (Nature reviews Immunology 2011

\section{BAHAN DAN METODE}

Jenis Penelitian ini menggunakan desain eksperimen in vitro di dalam laboratorium dengan randomized post test only controlled group design pada kultur peripheral blood mononuclear cell (PBMC) ketiga kelompok sampel yang sebelumnya diinduksi dengan antigen ESAT-6 Mycobacterium tuberculosis. Subyek penelitian dibagi menjadi tiga kelompok, yaitu kelompok orang sehat dengan mantoux tes negatif, kelompok TB laten dengan mantoux tes positif dan kelompok TB pasien TB aktif dengan mantoux tes positif. PBMC diinduksi dengan protein rekombinan Mycobacterium tuberculosis dan dikultur selama 4-5 hari, kemudian di panen. Limfosit dalam darah akan terpapar dengan antigen ESAT-6 dalam tabung selama inkubasi, individu yang terinfeksi kuman TB mempunyai limfosit yang mampu mengenai antigen tersebut dan akan mensekresikan INF $\gamma$ dan IL-10. Supernatan kultur dipisahkan setelah inkubasi dan diperiksa dengan metode sandwich ELISA untuk mengukur INF $\gamma$ dan IL-10.

Pengumpulan data dilakukan dengan lembar pengumpulan data. Semua data yang terkumpul dalam penelitian disusun dalam bentuk tabel, diagram dan grafik. Perbedaan rerata kadar IFN- $\gamma$ dan IL-10 dari masing masing kelompok dianalisis dengan one way ANOVA dengan tingkat kebermaknaan $\mathrm{p}<$ 0,05 .

\section{HASIL PENELITIAN}

Penelitian ini dilakukan sejak bulan Januari 2016 sampai dengan Juni 2016. Subyek penelitian adalah penderita TB aktif, perawat kontak TB (TB laten) dan orang sehat dengan TST negatif. Sampel penderita TB aktif dan perawat kontak TB diambil dari RS Paru Surabaya, untuk orang sehat diambil dari relawan FK-UWKS. Jumlah sampel yang memenuhi kriteria penerimaan sampel adalah 30 orang. Umur rearata sampel 36,5 tahun, terdiri dari umur $\leq 20$ tahun $6,7 \%$ ( 1 orang sehat, 1 
orang TB aktif), umur $21-30$ tahun $26,7 \%$ ( 3 orang sehat, 3 TB laten, 2 TB aktif), umur 31-40 tahun $33,31 \%$ ( 2 orang sehat, 4 TB laten, 4 TB aktif), umur $41-50$ tahun $23,3 \%$ ( 3 orang sehat, 3 TB laten, 1 TB aktif), umur $>50$ tahun $10 \%$ ( 1 orang sehat, 2 TB aktif).

Data umur subyek penelitian

\begin{tabular}{|c|c|c|c|c|}
\hline $\begin{array}{l}\text { Um } \\
\text { ur }\end{array}$ & $\begin{array}{c}\text { Kelomp } \\
\text { ok } \\
\text { Sehat }\end{array}$ & $\begin{array}{c}\text { Kelomp } \\
\text { ok } \\
\text { TB laten }\end{array}$ & $\begin{array}{c}\text { Kelomp } \\
\text { ok } \\
\text { TB aktif }\end{array}$ & Total \\
\hline$<20$ & $1(10 \%)$ & $0(0 \%)$ & $1(10 \%)$ & $2(6,7)$ \\
\hline $\begin{array}{l}21- \\
30\end{array}$ & $3(30 \%)$ & $3(30 \%)$ & $2(20 \%)$ & $\begin{array}{l}8 \\
(26,7 \%\end{array}$ \\
\hline $\begin{array}{l}31- \\
40\end{array}$ & $2(20 \%)$ & $4(40 \%)$ & $4(40 \%)$ & $\begin{array}{l}10 \\
(33,33 \\
\%)\end{array}$ \\
\hline $\begin{array}{l}41- \\
50\end{array}$ & $3(30 \%)$ & $3(30 \%)$ & $1(10 \%)$ & $\begin{array}{l}7 \\
(23,3 \% \\
\\
\end{array}$ \\
\hline$>50$ & $1(10 \%)$ & $0(0 \%)$ & $2(20 \%)$ & $\begin{array}{l}3 \\
(10 \%)\end{array}$ \\
\hline $\begin{array}{l}\text { Tota } \\
1\end{array}$ & $\begin{array}{l}10 \\
(100 \%)\end{array}$ & $\begin{array}{l}10 \\
(100 \%)\end{array}$ & $\begin{array}{l}10 \\
(100 \%)\end{array}$ & $\begin{array}{l}30 \\
(100 \%)\end{array}$ \\
\hline
\end{tabular}

Jumlah sampel yang berjenis kelamin laki-laki 17 orang $(56,6 \%)$ dan perempuan 13 orang $(43,3 \%)$.

Data jenis kelamin subyek penelitian

\begin{tabular}{|l|l|l|l|l|}
\hline $\begin{array}{c}\text { Jenis } \\
\text { kelami } \\
\text { n }\end{array}$ & $\begin{array}{c}\text { Kelom } \\
\text { pok } \\
\text { Sehat }\end{array}$ & $\begin{array}{c}\text { Kelom } \\
\text { pok } \\
\text { TB } \\
\text { laten }\end{array}$ & $\begin{array}{l}\text { Kelom } \\
\text { pok } \\
\text { TB } \\
\text { aktif }\end{array}$ & Total \\
\hline $\begin{array}{l}\text { Laki- } \\
\text { laki }\end{array}$ & $5(50 \%)$ & $5(50 \%)$ & $7(70 \%)$ & $\begin{array}{l}17 \\
(56,6 \\
\%)\end{array}$ \\
\hline $\begin{array}{l}\text { Peremp } \\
\text { uan }\end{array}$ & $5(50 \%)$ & $5(50 \%)$ & $3(30 \%)$ & $\begin{array}{l}13 \\
(43,3 \\
\%\end{array}$ \\
\hline Jumlah & $\begin{array}{l}10 \\
(100 \%)\end{array}$ & $\begin{array}{l}10 \\
(100 \%)\end{array}$ & $\begin{array}{l}10 \\
(100 \%)\end{array}$ & $\begin{array}{l}30 \\
(100 \\
\%)\end{array}$ \\
\hline
\end{tabular}

Orang sehat dan perawat kontak TB (TB laten) pada penelitian ini diperiksa foto ronsen dada, TST dan pemeriksaan sputum BTA (baksil tahan asam). Hasil foto ronsen orang sehat dan
TB laten, semuanya normal. Hasil TST pada orang sehat adalah negatif, sedangkan pada TB laten hasilnya positif dengan rincian ukuran diameter indurasi TST $10 \mathrm{~mm}$ sebanyak 3 orang dan ukuran diameter indurasi TST $>10 \mathrm{~mm}$ sebanyak 7 orang.

Hasil BTA orang sehat dan TB laten semuanya negatif. Subyek TB aktif didiagnosis berdasarkan gejala klinis dan pemeriksaan sputum BTA. Hasil sputum BTA subyek TB aktif semuanya positif.

Pemeriksaan laboratorium subyek penelitian

\begin{tabular}{|l|l|l|l|}
\hline \multicolumn{1}{|c|}{ Parameter } & \multicolumn{1}{|c|}{ Sehat } & TB laten & TB aktif \\
\hline 1. Jumlah & 10 & 10 & 10 \\
2. Rerata umur & 34,5 & 36,6 & 38,4 \\
(tahun) & $(18-51)$ & $(26-47)$ & $(20-65)$ \\
3. Foto ronsen & Normal & Normal & Normal \\
dada & Negatif & Positif & - \\
4. TST & & 3 & \\
$10 \mathrm{~mm}$ & Negatif & Negatif & Positif \\
& & & \\
>10 mm & & & \\
5. BTA & & & \\
\hline
\end{tabular}

Hasil Pemeriksaan Kadar IFN- $\gamma$

Setelah PBMC distimulasi dengan PHA dan diukur dengan ELISA, didapatkan kadar IFN- $\gamma$ pada orang sehat berkisar antara 81,29 $137,78 \mathrm{pg} / \mathrm{mL}$, pada TB laten 68,21 - 137,3 $\mathrm{pg} / \mathrm{mL}$ dan pada TB aktif $66,17-151,66 \mathrm{pg} / \mathrm{mL}$.

Setelah PBMC distimulasi dengan ESAT-6 dan diukur dengan ELISA, didapatkan kadar IFN- $\gamma$ pada orang sehat berkisar antara 95,84 - 135, $47 \mathrm{pg} / \mathrm{mL}$, pada TB laten $74,6-$ $142,2 \mathrm{pg} / \mathrm{mL}$ dan pada TB aktif 72,67 - 154,21 $\mathrm{pg} / \mathrm{mL}$.

Kadar IFN- $\gamma$ setelah distimulasi ESAT-6 dan PHA.

\begin{tabular}{|l|ll|ll|ll|}
\hline & \multicolumn{2}{|c|}{ Sehat } & \multicolumn{2}{|c|}{ TB laten } & \multicolumn{2}{|c|}{ TB aktif } \\
\hline ESAT- & 93,84 & - & 74,6 & - & 72,67 & - \\
6 & 135,47 & & 142,2 & & 154,21 & \\
\hline PHA & 81,29 & - & 68,21 & - & 66,17 & - \\
& 137,78 & & 137,03 & & 151,66 & \\
\hline
\end{tabular}

Hasil Pemeriksaan Kadar IL-10.

Setelah PBMC distimulasi dengan PHA dan diukur dengan ELISA, didapatkan kadar IL- 
10 orang sehat berkisar antara $168,35-301,74$ $\mathrm{pg} / \mathrm{mL}$, pada TB laten $128,99-196,14 \mathrm{pg} / \mathrm{mL}$ dan pada TB aktif $220,28-288,73 \mathrm{pg} / \mathrm{mL}$.

Setelah PBMC distimulasi dengan ESAT-6 dan diukur dengan ELISA, didapatkan kadar IL-10 pada orang sehat berkisar antara $161,89-282,57 \mathrm{pg} / \mathrm{mL}$, pada TB laten $145,28-$ $218,64 \mathrm{pg} / \mathrm{mL}$ dan pada TB aktif 232,95 $294,07 \mathrm{pg} / \mathrm{mL}$.

Kadar IL-10 setelah distimulasi ESAT-6 dan PHA

\begin{tabular}{|l|llll|ll|}
\hline \multicolumn{1}{|c|}{ IL-10 } & \multicolumn{2}{|c|}{ Sehat } & \multicolumn{2}{|c|}{ TB laten } & \multicolumn{2}{|c|}{ TB aktif } \\
\hline ESAT- & 161,89 & - & 145,28 & - & 232,05 & - \\
6 & 282,57 & & 218,64 & & 294,07 & \\
\hline PHA & 168,35 & - & 128,99 & - & 220,28 & - \\
& 301,74 & & 196,14 & & 288,73 & \\
\hline
\end{tabular}

Profil Sekresi IFN- $\gamma$ pada masing-masing kelompok.

Data hasil pemeriksaan kadar IFN- $\gamma$ dan IL-10 dari masing-masing kelompok dan perlakuan tersebut selanjutnya dilakukan analisis statistik menggunakan uji One- Sample Kolmogorov-Smirnov, dan hasilnya data berdistribusi normal ( $>0,05)$, sehingga dilanjutkan dengan uji One-way ANOVA.

Hasil analisis uji One-way ANOVA menunjukkan sekresi IFN- $\gamma$ oleh PBMC setelah distimulasi dengan PHA, pada TB aktif lebih tinggi daripada TB laten dan orang sehat, namun tidak bermakna $(p=0,916)$. Nilai rerata kadar IFN- $\gamma$ pada TB aktif $112,0290 \pm 20,1171 \mathrm{pg} / \mathrm{mL}$, TB laten $107,3910 \pm 20,2282 \mathrm{pg} / \mathrm{mL}$ dan orang sehat $108,30 \pm 15,3715 \mathrm{pg} / \mathrm{mL}$.

Sekresi IFN- $\gamma$ oleh PBMC setelah distimulasi dengan ESAT-6, pada TB aktif lebih tinggi daripada TB laten dan orang sehat, namun tidak bermakna $(\mathrm{p}=0,434)$. Kadar rerata IFN- $\gamma$ pada TB aktif $120,1340 \pm 24,8701 \mathrm{pg} / \mathrm{mL}$, lebih tinggi daripada kadar rerata TB laten 115,1340 \pm $22,8190 \mathrm{pg} / \mathrm{mL}$ dan orang sehat $111,6920 \pm$ $14,7769 \mathrm{pg} / \mathrm{mL}$. Berdasarkan uji statistik tidak ada perbedaan bermakna kadar rerata antara TB aktif dengan TB laten maupun dengan orang sehat.

Uji statistik sekresi IFN- $\gamma$

\section{Rerata kadar IFN- $\gamma(\mathrm{pg} / \mathrm{mL})$}

\begin{tabular}{|l|l|l|l|l|}
\hline & \multicolumn{1}{|c|}{ Sehat } & TB laten & TB aktif & \multicolumn{1}{|l|}{ P } \\
\hline ESAT & 111,692 & 115,134 & 120,228 & 0,43 \\
-6 & $9 \quad \pm$ & $0 \quad \pm$ & $0 \quad \pm$ & 4 \\
& 14,7769 & 22,8190 & 24,8701 & \\
\hline PHA & 108,300 & 107,391 & 112,029 & 0,61 \\
& $0 \quad \pm$ & $0 \pm \pm$ & $0 \quad \pm$ & 9 \\
& 15,3715 & 20,2282 & 20,1171 & \\
\hline
\end{tabular}

Bermakna jika $\mathrm{p}<0,05$

Profil Sekresi IL-10 pada masing-masing kelompok.

Berdasarkan hasil uji normalitas yang menyatakan bahwa data nominal kadar IL-10 terdistribusi normal dan variabel yang akan diuji kadar IL-10 merupakan variabel tidak berpasangan dan lebih dari dua kelompok, maka uji komparatif yang digunakan dalam penelitian ini adalah uji Kruskal-Walls. Hasil yang diperoleh untuk kadar IL-10 diperoleh nilai $\mathrm{p}=0,0003(\mathrm{p}<0,05)$.

Berdasarkan uji Kruskal-Walls tersebut dapat disimpulkan bahwa terdapat perbedaan kadar IL-10 yang bermakna (significant) diantara dua kelompok sampel. Tahap selanjutnya untuk mengetahui kelompok mana yang mempunyai perbedaan, maka harus dilakukan analisis Post Hoc. Uji yang digunakan untuk melakukan analisis Post Hoc untuk uji Kruskal-Walls adalah dengan uji Mann-Whitney. Hasil yang diperoleh setelah melakukan uji Mann-Whitney adalah sebagai berikut :

*) Untuk ESAT-6

- Orang sehat dengan TB laten, $\mathrm{p}=0,003$ $(\mathrm{p}<0,05)$

- Orang sehat dengan TB aktif, $\mathrm{p}=0,762$ $(\mathrm{p}>0,05)$

- TB laten dengan TB aktif, $\mathrm{p}=0.000(\mathrm{p}<0,05)$

*) Untuk PHA

- Orang sehat dengan TB laten, $\mathrm{p}=0,001$ $(\mathrm{p}<0,05)$

- Orang sehat dengan TB aktif, $\mathrm{p}=0,705$ $(\mathrm{p}>0,05)$

- TB laten dengan TB aktif, $\mathrm{p}=0,000(\mathrm{p}<0,05)$

Sekresi IL-10 oleh PBMC setelah distimulasi dengan ESAT-6, terdapat perbedaan bermakna $(\mathrm{p}=0,000)$, pada ketiga kelompok.

Uji statistik sekresi IL-10

\section{Rerata kadar IL-10 (pg/mL)}




\begin{tabular}{|l|l|l|l|l|}
\hline & \multicolumn{1}{|c|}{ Sehat } & TB laten & TB aktif & \multicolumn{1}{|c|}{ P } \\
\hline ESAT & 235,700 & 169,331 & 251,698 & 0,00 \\
-6 & $0 \quad \pm$ & $0 \quad \pm$ & $0 \quad \pm$ & 0 \\
& 41,6337 & 22,2658 & 18,1132 & \\
\hline PHA & 248,630 & 166,475 & 257,560 & 0,00 \\
& $0 \quad \pm$ & $0 \quad \pm$ & 0 & 0 \\
& 40,1655 & 20,7824 & $\pm 23,668$ & \\
& & & 1 & \\
\hline
\end{tabular}

Kadar rerata IL-10 pada TB aktif $(251,6980 \pm 18,1132 \mathrm{pg} / \mathrm{mL})$ lebih tinggi daripada kadar rerata orang sehat $(235,70 \pm$ $41,6337 \mathrm{pg} / \mathrm{mL})$ dan TB laten $(169,3310 \pm$ $22,2658 \mathrm{pg} / \mathrm{mL})$. Berdasar uji statistik terdapat perbedaan bermakna antara kadar IL-10 orang sehat dengan TB laten ( $p=0,003)$, juga antara TB aktif dengan TB laten $(p=0,000)$. Sedangkan pada orang sehat dibandingkan dengan TB aktif tidak ada perbedaan bermakna rerata kadar IL$10(\mathrm{p}=0,762)$.

Perbedaan kadar rerata IL-10 setelah distimulasi dengan ESAT-6.

ESAT - 6

\begin{tabular}{|l|l|l|ll|}
\hline Sehat & $235,70 \pm$ & $235,70 \pm$ & & \\
& 41,6337 & 41,6337 & & \\
\hline TB & 169,3310 & & 169,3310 & \pm \\
laten & \pm & & 22,2658 & \\
& 22,2658 & & & \\
\hline TB & & 251,6980 & 251,6980 & \pm \\
aktif & & \pm & 18,1132 & \\
& & 18,1132 & & \\
\hline P & 0,003 & 0,762 & 0,000 & \\
\hline
\end{tabular}

*Bermakna jika $\mathrm{p}<0,005$

Hasil analisis uji One-way ANOVA menunjukkan sekresi IL-10 oleh PBMC setelah distimulasi oleh PHA juga terdapat perbedaan bermakna $(p=0,000)$ pada ketiga kelompok. Berdasarkan uji statistik terdapat perbedaan bermakna antara kadar rerata IL-10 pada orang sehat dan TB laten $(p=0,001)$, juga antara TB aktif dan TB laten $(p=0,000)$. Sedangkan pada orang sehat dibandingkan dengan TB aktif tidak ada perbedaan bermakna rerata kadar IL-10 $(\mathrm{p}=0,705)$.

Perbedaan kadar rerata IL-10 setelah distimulasi dengan PHA

PHA
\begin{tabular}{|l|l|ll|ll|}
\hline Sehat & $\begin{array}{l}248,63 \\
40,1655\end{array}$ & $\begin{array}{l}248,63 \\
40,1655\end{array}$ & \pm & & \\
\hline TB & 166,4750 & & 166,4750 & \pm \\
laten & \pm & & 20,7824 & \\
& 20,7824 & & & & \\
\hline TB & & 257,56 & \pm & 257,56 & \pm \\
aktif & & 23,6681 & 23,6681 & \\
\hline P & 0,001 & 0,705 & 0,000 & \\
& & & & & \\
\hline
\end{tabular}

*Bermakna jika $\mathrm{p}<0,005$

\section{PEMBAHASAN}

\subsection{Karakteristik Subyek Penelitian}

Penderita TB paru aktif dalam penelitian ini proporsi laki-laki $70 \% \%$, lebih besar daripada perempuan sebanyak $30 \%$. Data ini sesuai dengan hasil Riskerdas 2013 bahwa kasus BTA + pada laki-laki lebih tinggi daripada perempuan, yakni hampir 1,5 kali dibandingkan kasus BTA+ pada perempuan (Kemenkes Republik Indonesia, 2014). Disatu sisi laki-laki bersifat lebih aktif dalam pekerjaannya dan lebih banyak bertemu dengan orang, sehingga lebih berpotensi tertular penyakit TBC.

Pada penelitian ini penderita TB paru aktif ditemukan di usia $\leq 50$ tahun sebesar $80 \%$. Hal ini menunjukkan bahwa penyakit TB menyerang usia produktif. Sekitar $75 \%$ pasien TB adalah kelompok usia yang paling produktif secara ekonomis, yaitu usia $15-50$ tahun (Depkes RI, 2011). Setelah bertahun-tahun TB primer akan menjadi TB post primer, umumnya pada usia 15 - 40 tahun.

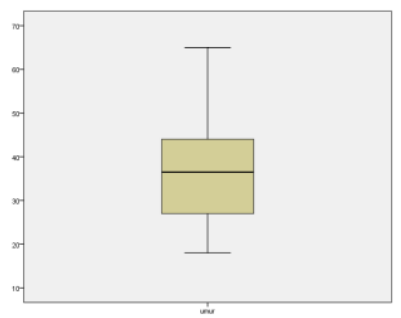


5.1 Karakteristik umur subyek penelitian

\subsection{Profil Sekresi IFN- $\gamma$ dan IL-10 pada masing-masing kelompok}

Sitokin merupakan molekul mediator pada imunitas spesifik (didapat). Imunitas spesifik terhadap Mycobacterium tuberculosis, dihasilkan ketika sel $\mathrm{CD}^{+}$mengenali antigen yang dipresentasikan oleh molekul MHC kelas II. Sel CD4+ mensekresi sitokin yang paling penting, yakni IFN- $\gamma$, IL-2 dan TNF- $\alpha$ yang mengaktifkan makrofag untuk memusnahkan mikrobakteri.

Respons imun terhadap Mycobacterium tuberculosis selain respons imun sel Th-1 yang protektif juga merangsang respons imun sel Th2 yang diduga tidak protektif. Sel makrofag mengeluarkan IL-12, menginduksi sel $\mathrm{T}$ naïve (Th-0) berdiferensiasi menjadi sel Th-1 dan del Th-2. Selanjutnya IL-1 dari makrofag menginduksi sel Th-1 untuk memproduksi sitokin IFN- $\gamma$, IL-2 dan TNF- $\alpha$. IFN- $\gamma$ dan IL-2 menginduksi sel Th-2 untuk memproduksi sitokin IL-4, IL-5, IL-6 dan IL-10 (Sudiana, IK. 2014). Selanjutnya IL-4, IL-5 dan IL-6 menginduksi limfosit B mengalami diferensiasi menjadi sel memori dan sel plasma untuk menghadilkan antibodi (Ab).

Hasil penelitian menunjukkan bahwa kadar rerata IFN- $\gamma$ setelah distimulasi dengan ESAT-6 pada penderita TB aktif lebih tingi daripada TB laten dan orang sehat. Tidak ada perbedaan bermakna $(p=0,434)$ antara ketiga kelompok sampel. Kadar INF- $\gamma$ yang lebih tinggi bisa dipahami karena terdapat respons imun protektif terhadap infeksi kuman TB. Tidak ada perbedaan bermakna antara ketiga kelompok sampel, disebabkan oleh beberapa hal sebagai berikut, pertama mengenai status gizi penderita TB aktif cenderung malnutrisi, sehingga respons imun tidak berjalan secara maksimal. Kedua, pada umumnya, penderita yang berkunjung ke rumah sakit bukan penderita TB aktif baru, suatu eksaserbasi akut yakni penderita lama yang mengalami reaktivasi setelah sempat sembuh beberapa waktu. Ketiga, penderita yang telah didiagnosis TB namun tidak segera berobat anti-TB dan sistem kesehatan berjenjang, fasilitas kesehatan 1 merujuk ke rumah sakit paru. Kondisi tersebut mengakibatkan penurunan respons imun, sehingga kadar IFN- $\gamma$ tidak terlalu tinggi. Keempat, dari data penelitian menunjukkan bahwa kadar IL-10 penderita TB aktif cukup tinggi $(251,6980 \pm 18,1132 \mathrm{pg} / \mathrm{mL})$. IL-10 merupakan sitokin anti inflamasi yang menurunkan proliferasi sel Th-1 dan menghambat aktifitas makrofag, akibatnya terjadi penurunan respons imun terhadap infeksi tuberculosis, sehingga kadar IFN- $\gamma$ tidak tinggi. Penelitian lain oleh Hanne Veenstra et.al 2007, menemukan prosentase IFN- $\gamma$ yang disekresi oleh sel $\mathrm{T}$ limfosit $\mathrm{CD}^{+}$pada pasien $\mathrm{TB}$ saat didiagnosis. Secara bermakna lebih tinggi daripada kontrol (Veenstra Hanne et al, 2007).

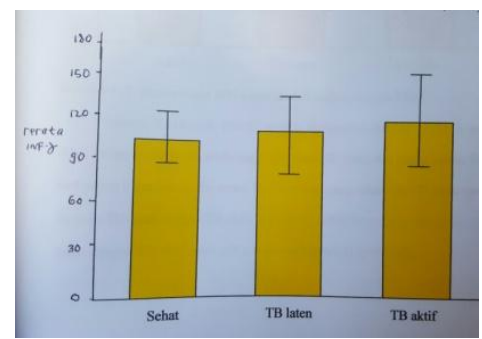

5.2 Kadar rerata IFN- $\gamma$ setelah distimulasi dengan ESAT-6

Sekresi IFN- $\gamma$ oleh PBMC setelah distimulasi dengan PHA, tidak ada perbedaan bermakna pada ketiga kelompok $(\mathrm{p}=0,619)$. Kadar IFN- $\gamma$ pada penderita TB aktif lebih tinggi daripada TB laten dan orang sehat dan tidak bermakna $(\mathrm{p}>0,05)$.

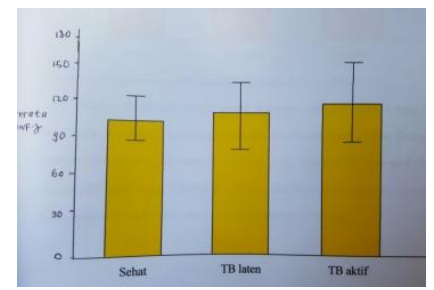

5.3 Kadar rerata IFN- $\gamma$ setelah distimulasi dengan PHA

Sekresi IL-10 oleh PBMC setelah distimulasi dengan ESAT-6 pada TB aktif, kadar rerata IL-10 lebih tinggi daripada TB laten dan 
orang sehat. Terdapat perbedaan bermakna kadar rerata IL-10 antara orang sehat dan TB laten $(p=0,003)$ da pada TB laten dengan TB aktif $(p=0,000)$. Sebaliknya kadar rerata IL-10 orang sehat dengan TB aktif tidak ada perbedaan bermakna $(\mathrm{p}=0,762)$.

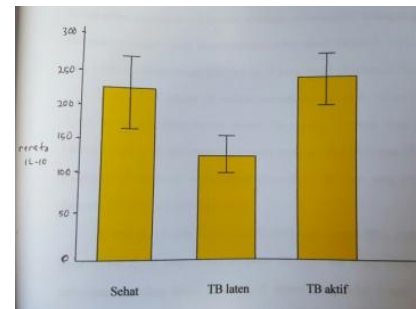

5.4 Kadar rerata IL-10 setelah distimulasi dengan ESAT-6

Pada penderita tuberkulosis juga diekspresikan berbagai sitokin anti inflamasi yang dapat menurunkan respons imun terhadap Mycobacterium tuberculosis, serta menghambat peningkatan respons inflamasi. Apabila jumlah sitokin tersebut berlebihan, dapat mengakibatkan kegagalan dalam pengontrolan infeksi tuberkulosis.

Interleukin-10 (IL-10) bisa menonaktifkan makrofag dan menghambat proliferasi sel Th1 yang berakibat menurunkan respons imun terhadap Mycobacterium tuberculosis. IL-10 diproduksi oleh el Th-2, subset sel $\mathrm{T} \mathrm{CD}^{+}$termasuk $\mathrm{Th}-17$, sel $\mathrm{B}$ limfosit, netrofil, makrofag dan beberapa subset sel dendritik. IL-10 juga menghambat proses fagositosis dan eliminasi mikroba seperti Mycobacterium tuberculosis dengan cara membatasi produksi intermediate oksigen dan nitrogen reaktif yang dimediasi oleh aktifasi IFN- $\gamma$. IL-10 dapat menghambat pematangan fagosom sehingga memfasilitasi kelangsungan hidup dan perkembangan baksil Mycobacterium tuberculosis (Redford, 2011). TB paru yang berat dikaitkan dengan produksi IL-10 yang tinggi (William, 2004).

Pada PBMC pasien TB terdapat peningkatan sekresi IL-10 dan tidak IFN- $\gamma$, hal ini menunjukkan bahwa pasien TB memiliki respons imun sel Th-2, sedangkan pada TB laten memiliki respons imun sel Th-1 (Schlugen,1998). Hasil penelitian ini dapat dilihat dari kadar rerata IL-10 TB laten yang lebih rendah daripada TB aktif maupun orang sehat.

Sekresi IL-10 oleh PBMC setelah distimulasi dengan PHA, pada TB aktif kadar rerata IL-10 lebih tinggi daripada TB laten dan orang sehat. Terdapat perbedaan bermakna kadar rerata IL-10 antara orang sehat dengan TB laten $(\mathrm{p}=0,001)$ dan TB laten dengan TB aktif $(\mathrm{p}=0,000)$. Kadar rerata $\mathrm{IL}-10$ orang sehat dengan TB aktif tidak ada perbedaan bermakna $(\mathrm{p}=0,705)$.

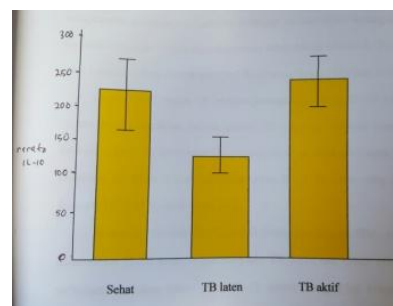

Kadar 5.5 Kadar rerata IL-10 setelah distimulasi PHA

Berbagai studi menunjukkan bahwa ekspresi IL-10 dapat meningkat secara bermakna pada penderita tuberkulosis aktif. Lipoarabinomanan (LAM) yang merupakan komponen utama dinding sel Mycobacterium tuberculosis dapat mengikat molekul DC-SIGN (Dendritic Cell-Specific Intercellular Molecule3-Grobing Non-Integrin, dikenal dengan nama CD-209) yang diekspresikan di permukaan sel dendritik. Ikatan CD-209 dengan LAM mengakibatkan terhambatnya proses pematangan sel dendritik oleh DC-SIGN, penurunan produksi IL-12, dan menginduksi sel dendritik untuk mensekresikan IL-10. Interleukin-10 yang diekspresikan mengakibatkan terhambatnya presentasi antigen, ekspresi molekul MHC dan ekspresi reseptor kostimulator (Dietrich,2009).

\section{Kesimpulan}

Hasil dari penelitian ini, dapat disimpulkan sebagai berikut :

1. Kadar IFN- $\gamma$ setelah di stimulasi antigen ESAT-6 pada orang sehat antara 98,84 $135,47 \mathrm{pg} / \mathrm{mL}$, pada TB laten 74,6 $142,2 \mathrm{pg} / \mathrm{mL}$ dan TB aktif 72,67 - 154,21 $\mathrm{pg} / \mathrm{mL}$. Hal tersebut menunjukkan bahwa sekresi IFN- $\gamma$ setelah PBMC distimulasi 
dengan antigen ESAT-6, tidak ada perbedaan bermakna pada ketiga kelompok. Tidak ada perbedaan pada penelitian ini, dikarenakan respons imun yang tidak optimal, khususnya pada penderita TB aktif.

2. Kadar IL-10 setelah distimulasi antigen ESAT-6, pada orang sehat didapatkan antara $161,89-282,57 \mathrm{pg} / \mathrm{mL}$, TB laten $145,28-218,64 \mathrm{pg} / \mathrm{mL}$ dan TB aktif $232,05-294,07 \mathrm{pg} / \mathrm{mL}$. Uji statistic didapatkan $\mathrm{p}=0,000 \quad(\mathrm{p}<0,05)$, hal ini menunjukkan bahwa terdapat perbedaan bermakna sekresi IL-10 di ketiga kelompok. Pada TB aktif didapatkan peningkatan sekresi IL-10 atau memiliki respons sel Th-2 yang meningkat.

3. Kadar IL-10 pada TB laten lebih rendah dibandingkan dengan orang sehat dan TB aktif, menunjukkan bahwa respon Th-1 lebih dominan dalam melawan Mycobacterium tuberculosis, sehingga bersifat protektif.

4. Antigen ESAT-6 bersifat merangsang respons sel Th-1, sehingga kemungkinan dapat dijadikan sebagai kandidat vaksin, namun masih diperlukan penelitian lenih lanjut.

5. Terdapat perbedaan pola sekresi IFN- $\gamma$ dan IL-10 PBMC orang sehat, TB laten dan TB aktif setelah distimulasi antigen ESAT-6

\section{DAFTAR PUSTAKA}

Abbas Abul K., Lichman Andrew H \& Pillai Shiv 2014. Effector Mechanisms of $\mathrm{T}$ CellMediated Immunity Functions of T Cells in Host Defense. Basic Immunology : Functions And Disorders Of The Immune System. Philadelphia USA: Elsevier Saunders.

Afif E. Taufik. Medison I 2013. Analisis kadar antibodi anti ESAT-6 pada pasien tuberkulosis paru. J Respir Indo,33:17-25.

Beamen GI. Interleukin 10 Promotor Mycobacterium tuberculosis Disease Progression in CBA/ a Mice. The Journal of
Immunology. The American Association of Immunologist. 2008.

Cardoso F. Antas P2002. T-Cell Responses to the Mycobacterium tuberculosis-specific antigen ESAT-6 in brazilian tuberculosis patients. Infect Immun vol7,no12,p.6707-6714.

Corbiere V. Pottier G. Bonkain F 2012. Risk stratification of latent tuberculosis defined by combined interferon gamma release assays. Plos One,7:e43285.

Day CI, Abrahams DA. Lerumo L 2011. Functional capacity of Mycobacterium tuberculosis-specific $\mathrm{T}$ cell responses in humans is associated with mycobacterial load. $J$ Immunol ; 187:2222-32.

Devi A 2012. Hubungan usia, jenis kelamin dan status nutrisi dengan kejadian anemia pada pasien tuberkulosis di RSUP Dr. Kariadi Semarang. Universitas Diponegoro.

Fitriani F. Yunus F 2011. Penyakit paru obstruksi kronik sebagai penyakit sistemik. FKUI. Jurnal Respirologi Indonesia.

Gyoung HY, Stolinske PG, Smith AB. Combination of Cytokine Responses Indicative of Latent TB and Active TB in Malawian Adults. Plos One. November 2013:8(11).

Gustiani N. Parwati I. Tjandrawati A. Lismayanti L 2014. Validitas pemeriksaan complex specific antigen Mycobacterium tuberculosis region of difference 1-3 metode rapid immunochromatography pada sputum penderita tuberkulosis paru. RS Dr. Hasan Sadikin Bandung.46(4):241-46.

Ganguly N. Giang P 2008. Mycobacterium tuberculosis secretory proteins CFP-10, ESAT-6 and the CFP-10 : ESAT-6 complex inhibit lipopolysaccharide-induced NF-kB transactivation by downregulation of reactive oxidative species production. Immunology and cell Biology 86,98106;doi:10.1038/sj.icb.7100117. 
Handojo I 2003. Pengantar imunoasai dasar. Airlangga University Press. Page 112.

Harari A. Rozot V. Enders FB, et al. 2011. Dominant TNF- $\alpha$ Mycobacterium tuberculosisspesific CD4+ $\mathrm{T}$ Cell responses discriminate between latent infection and active disease. Nat Me 17:372-6.

Hasugian A. Wibowo H. Tjitra E 2011. Hubungan kadar hemoglobin dengan respons sitokin proinflamasi dan anti inflamasi pada penderita infeksi Plasmodium falciparum dan Plasmodium vivax di Timika, Papua. Biomedik FKUI.

Hermayanti D 2014. Respons imun dan pemeriksaan serologi pada tuberkulosis. Fakultas Kedokteran Universitas Muhammadiyah Malang.

Irawati L. Acang Nusirwan. Irawat N 2008. Ekspresi Tumor Necrosis Factor- Alfa dan Interteukin-10 pada infeksi malaria falciparum. Majalah Kedokteran Andalas, No1, Vol 32.

Indah A 2013. Hubungan tuberkulosis dengan diabetes melitus. RSUP Gatot Subroto Jakarta.

Jalius 2012. Studi mekanisme interferon dalam pembentukan sistem pertahanan tubuh. Universitas Jambi.

Jordao L. Vieira OV 2011. Tuberculosis : New aspects of an old disease. International Journal of Cell Biology,1-13.

Kemenkes Republik Indonesia 2014. Profil kesehatan Indonesia tahun 2013, JakartaIndonesia.

Kumar V, Abbas AK, Fausto N, Aster JC 2010. Robbins and cotran Pathologic Basis of Disease. Ed 8. Philadelphia : Saunders Elseviers.

Kusuma C 2007. Diagnostik tuberkulosis paru. Sari Pediatri,Vol 8, No 4,143-151.

Kaihena M 2013. Propolis sebagai imunostimulator terhadap infeksi
Mycobacterium tuberculosis. FMIPA Universitas Pattimura.

Kenyorini, Suradi, Surjanto E 2012. Uji tuberkulin. Bagian Pulmonologi dan Kedokteran Respirasi FK UNS/ RSUD Dr. Moewardi Surakarta.

Lume V. Souza D 2010. Immunological diagnosis of tuberculosis based on recombinant antigens ESAT-6 and CFP-10 in children from an endemic area in northeast Brazil. Scand $J$ Immunol. Nov;72(5):460-8.doi:10.1111/j.13653083.2010.12459.x.

Laurens A. Ravn P. Agger A. Pollock J. Andersen P 2000. Diagnosis of tuberculosis based on the two specific antigens ESAT- 6 and CFP-10. Clinical and Vaccine Immunology. 7(2):155.doi:10.1128/CDLI.7.2.155-160.

Masniari L. Priyanti ZS. Aditama Y 2013. Faktor yang mempengaruhi kesembuhan penderita TB Paru. Departemen Pulmonologi Dan Ilmu Kedokteran Respirasi FKUI-RSUP Persahabatan Jakarta.

Moningkey L. Rampengan S. Pangemanan J 2012. Hubungan kadar TNF- $\alpha$ dengan fraksi ejeksi pada pasien gagal jantung kronik Di BLU/RSUP Prof. Dr. R.D. Kandou Manado.

Munk M. Arend S. Brock I. Ottenhoff T. Andersen P 2001. Use of ESAT-6 and CFP-10 antigens for diagnosis of extrapulmonary tuberculosis. J Infect Dis. 183 (1):175176.doi:10.1086/317663

Ngurah A 2011. Peningkatan TNF- $\alpha$ merupakan faktor resiko terjadinya Preeklamsia. RSUD Sanglah Denpasar.

Perhimpunan Dokter Paru Indonesia. Tuberkulosis, Pedoman Diagnosis dan Penatalaksanaan di Indonesia.2002.

Pratomo I, Burhan E. Tambunan V 2012. Malnutrition and tuberculosis. RS Persahabatan Jakarta. J Indon Med Assoc.62:230-7. 
Pollock K. Whitworth H 2013. T Cell immunophenotyping distinguishes active from latent tuberculosis. The Journal of Infectious Disease. Page 952-968.

Palomino JC. Leao SC. Ritacco V 2007. Tuberculosis 2007 : From basic science to patient care $1^{\text {st }}$ d.Argentina.Bouciller Kamps. p.26-52.

Rantam F 2003. Metode Imunologi. Airlangga University Press. Page 19-22.

Ravn P. Demissie A 1999. Human T cell responses to the SEAT-6 antigen from Mycobacterium tuberculosis. J Infect Dis. 179 (3).doi:10.1086/314640

Redford PS, Murray PJ. O'ga A. The Role of IL10 in Immune Regulation during M. tuberculosis Infection.Mucosal Immunology. Nature Publishing Grup. 2011.

Roostati R 2008. Analisis kadar interferon gamma pada penderita tuberkulosis paru dan bukan penderita tuberkulosis.Universitas Sumatera Utara.

Sharmo S, Bose M. Role of Cytokines in Immune Response to Pulmonary Tuberculosis. Asian Pacific Journal of Alergy and Immunology. 2001.

Siswanto. Sumarno 2009. Pengobatan suportif Vitamin D mempercepat konversi sputum dan perbaikan gambaran radiologis penderita tuberculosis. Universitas Brawijaya Malang.

Sudiana, I.K. Imunopatobiologi molekuler. Airlangga University Press (AUP) Surabaya. 2014.

Sutherland JS. Hill PC. Adetifa IM 2011. Identification of probable early-onset biomarkers for tuberculosis disease progression. Plos One.6:e25230.

Teguh Widjaja J, Jaseputra KD, Roostati R. Analisis Kadar Interferon Gamma pada
Penderita Tuberkulosis Paru dan Orang Sehat. Journal Respiratory Indonesia. 2010.

Vankayalapati R. Serum Cytokines Concentration Do Not Parallel Mycobacterium tuberculosis-Induced Cytokines Production In Patients with Tuberculosis. Infection Disease Society of America. 2002.

WHO 2014. Global tuberculosis report. WHO press.

Wasityastuti W. Subronto Y. Soesatyo M 2007. The profile of Interferon- $\gamma$ and Interleukin-10 in pulmonary tuberculosis patients. TMJ vol01,No01.p.13-22.

Wijayanti O. Wahyuningtyas R 2014. Tuberkulosis : Diagnosis dan tatalaksananya. Perhimpunan Dokter Paru Indonesia. .

Widjaja T. Jasaputra D. Roostati R 2010. Analisis kadar interferon gamma pada penderita tuberkulosis paru dan orang sehat. FK Universitas Kristen Maranatha. J Respir Vol 30, No2.

Widjaja T 2011. Infeksi Laten Tuberkulosis : Keseimbangan antara sistem imun pejamu dan strategi bertahan M. tuberculosis. Pulmonologi Fakultas Kedokteran Universitas Kristen Maranatha, RS Immanuel Bandung Indonesia. Continuing Medical Education 183/vol 38 no2. World Health Organization 2011. Global Tuberculosis Control 2011 : Geneva : World Health Organization.

Zhang J. Chen Y 2011. Interleukin-10 polymorphisms and tuberculosis susceptibility : a meta-analysis. Int $J$ Tuberc Lung Dis.15(5):594-601.doi:10.5588/ijtld.09.0703. 
Jurnal Biosains Pascasarjana Vol. 18 (2016) pp

(C) (2016) Sekolah Pascasarjana Universitas Airlangga, Indonesia 